\title{
Correction to: Neurons expressing the aryl hydrocarbon receptor in the locus coeruleus and island of Calleja major are novel targets of dioxin in the mouse brain
}

\author{
Eiki Kimura $^{1,2,3}$ (D) Masanobu Kohda ${ }^{1,2} \cdot$ Fumihiko Maekawa ${ }^{2}$ (D) $\cdot$ Yoshiaki Fujii-Kuriyama $^{4} \cdot$ Chiharu Tohyama $^{1,2,5}$ (D)
}

Published online: 18 June 2021

(c) The Author(s) 2021

\section{Correction to: Histochemistry and Cell Biology https://doi.org/10.1007/s00418-021-01990-1}

The article "Neurons expressing the aryl hydrocarbon receptor in the locus coeruleus and island of Calleja major are novel targets of dioxin in the mouse brain", written by Eiki Kimura, Masanobu Kohda, Fumihiko Maekawa, Yoshiaki Fujii-Kuriyama, and Chiharu Tohyama, was originally published electronically on the publisher's internet portal on 08 May 2021 without open access. With the author(s)' decision to opt for Open Choice the copyright of the article changed on 19 May 2021 to (C) The Author(s) 2021 and the article is forthwith distributed under a Creative Commons Attribution 4.0 International License, which permits use, sharing, adaptation, distribution and reproduction in any

The original article can be found online at https://doi.org/10.1007/ s00418-021-01990-1.

Eiki Kimura

eiki-kimura@umin.ac.jp

$\triangle$ Chiharu Tohyama

tohyama.chiharu@hestic.com

1 Laboratory of Environmental Health Sciences, Center for Disease Biology and Integrative Medicine, Graduate School of Medicine, The University of Tokyo, 7-3-1 Hongo, Bunkyo-ku, Tokyo 113-0033, Japan

2 Center for Health and Environmental Risk Research, National Institute for Environmental Studies, 16-2 Onogawa, Tsukuba 305-8506, Japan

3 Research Fellow, Japan Society for the Promotion of Science (JSPS), 5-3-1 Kojimachi, Chiyoda-ku, Tokyo 102-0083, Japan

4 Medical Research Institute, Molecular Epidemiology, Tokyo Medical and Dental University, 1-5-45 Yushima, Bunkyo-ku, Tokyo 113-8510, Japan

5 Faculty of Medicine, University of Tsukuba, 1-1-1 Tennodai, Tsukuba 305-8575, Japan medium or format, as long as you give appropriate credit to the original author(s) and the source, provide a link to the Creative Commons licence, and indicate if changes were made. The images or other third party material in this article are included in the article's Creative Commons licence, unless indicated otherwise in a credit line to the material. If material is not included in the article's Creative Commons licence and your intended use is not permitted by statutory regulation or exceeds the permitted use, you will need to obtain permission directly from the copyright holder. To view a copy of this licence, visit http://creativecommons. org/licenses/by/4.0.

The original article has been corrected.

Publisher's Note Springer Nature remains neutral with regard to jurisdictional claims in published maps and institutional affiliations. 